\title{
Perlakuan Benih Cabai (Capsicum annuum L.) dengan Rizobakteri untuk Mengendalikan Phytophthora capsici, Meningkatkan Vigor Benih dan Pertumbuhan Tanaman
}

\section{Seed Treatment of Hot Pepper (Capsicum annuum L.) using Rhizobacteria to Control Phytophthora capsici and to Improve Seed Vigor and Plant Growth}

\author{
Abubakar Ibrahim ${ }^{1}$, Satriyas Ilyas ${ }^{1 *}$, Dyah Manohara ${ }^{2}$ \\ ${ }^{1}$ Departemen Agronomi dan Hortikultura, Fakultas Pertanian, Institut Pertanian Bogor \\ (Bogor Agricultural University), Jl. Meranti, Kampus IPB Dramaga, Bogor 16680, Indonesia \\ Telp \& Faks. 62-251-8629353 e-mail agronipb@indo.net.id \\ ${ }^{2}$ Balai Penelitian dan Pengembangan Tanaman Obat dan Aromatik, Kementerian Pertanian. \\ Jl. Tentara Pelajar No. 3. Bogor, Indonesia. \\ *)Penulis untuk korespondensi : satriyas ilyas@yahoo.com
}

Disetujui 24 Desember 2013/ Published online 13 Februari 2014

\begin{abstract}
Rhizobacteria seed treatment was an alternative way instead of using chemicals to combat plant disease. The objectives of this research were (1) to select rhizobacteria isolates which inhibiting Phytophthora capsici growth; and (2) to study the effect of seed treatment using rhizobacteria on $\underline{P}$. capsici growth, seed vigor and plant growth of hot pepper. This research consisted of two experiments, both of experiments were arranged in completely randomized design using one factor. The first experiment consisted of five level treatments i.e. ST116B rhizobacteria, ST156 rhizobacteria, E3 rhizobacteria, metalaxyl, and control. The second experiment consisted of six level treatments i.e. ST116B rhizobacteria, ST156 rhizobacteria, E3 rhizobacteria, metalaxyl, positive control, and negative control. Results of in vitro experiment showed that 7 of 23 isolates tested i.e. ST156, E3, ST116B, ST81, SK7, ST116, and ST109B obstructed $\underline{P}$. capsici growth. seed treatments using ST116B, ST156, and E3 rhizobacteria increased seed vigor (vigor index). The best seed treatment increasing plant growth (number of leaves) and potentially controlling phytophthora blight disease was using ST116B rhizobacteria.
\end{abstract}

Keywords: dual culture, metalaxyl, phytophtora blight disease

\section{ABSTRAK}

Perlakuan benih menggunakan rizobakteri sebagai alternatif pengganti penggunaan bahan kimia untuk mengendalikan penyakit tanaman. Penelitian ini bertujuan (1) menyeleksi keefektifan isolat rizobakteri dalam menghambat pertumbuhan Phytophthora capsici secara in vitro, dan (2) mempelajari pengaruh perlakuan benih menggunakan rizobakteri terhadap pertumbuhan P. capsici, vigor benih dan pertumbuhan tanaman. Penelitian ini terdiri atas dua tahap percobaan, kedua percobaan tersebut menggunakan rancangan acak lengkap. Percobaan satu (pesemaian) terdiri atas lima taraf yaitu perlakuan benih dengan rizobakteri ST116B, ST156, E3, metalaksil, dan tanpa perlakuan (kontrol). Percobaan dua (di rumah kaca) terdiri atas enam taraf yaitu perlakuan rizobakteri ST116B, ST156, E3, metalaksil, kontrol positif, dan kontrol negatif. Terdapat 7 rizobakteri dari 23 isolat yang diuji yaitu ST156, E3, ST116B, ST81, SK7, ST116, dan ST109B menghambat pertumbuhan P. capsici secara in vitro. Perlakuan benih dengan rizobakteri ST116B, ST156, dan E3 nyata meningkatkan vigor benih pada tolok ukur indeks vigor. Perlakuan benih terbaik dalam meningkatkan pertumbuhan tanaman (jumlah daun) dan berpotensi mengendalikan penyakit busuk phytophthora pada tanaman cabai adalah dengan rizobakteri ST116B.

Kata kunci: busuk phytophthora, dual culture, metalaksil 


\section{PENDAHULUAN}

Suplai benih unggul dan bermutu memiliki peranan yang sangat penting dalam upaya untuk meningkatkan produktivitas tanaman. Mutu benih tersebut mencakup mutu genetis, fisiologis, fisik, dan patologis. Rendahnya produktivitas tanaman terutama disebabkan oleh rendahnya mutu benih yang digunakan. Mutu patologis berhubungan dengan infeksi patogen terbawa benih baik yang terdapat di dalam maupun di permukaan benih. Beberapa cendawan yang bersifat patogen terbawa benih cabai antara lain Colletotrichum capsici (antraknosa), Phytophthora capsici (busuk phytophthora), dan Rhizoctonia solani (damping off). Busuk phytophthora merupakan penyakit yang masih sulit dikendalikan karena belum tersedianya varietas yang resisten, metode pengendalian masih terbatas, dan patogen bersifat terbawa benih dan tular tanah (Miller et al. 1996; Roberts et al. 2000; Lows et al. 2002; Naik et al. 2008). Phytophthora capsici bersifat patogenik terhadap 25 genotipe cabai, lima genotipe dengan intensitas penyakit tertinggi diantaranya adalah Taro F1, Hot Pepper Tornado, F1 Hybrid Chilli, Bintoro, dan Marconi hot dengan persentase serangan 70-92 \% (Syamsudin 2010).

Perlakukan benih untuk mengendalikan penyakit busuk phytophthora pada umumnya dilakukan dengan fungisida sintetis, namun penggunaan pestisida sintetis mulai dikurangi dengan meningkatnya kesadaran masyarakat terhadap bahaya penggunaan zat pestisida kimia bagi lingkungan dan kesehatan. Oleh karena itu, agens hayati menjadi salah satu alternatif pengganti bahan kimia. Perlakuan invigorasi priming yang dikombinasikan dengan agens biokontrol (biopriming) mampu meningkatkan viabilitas dan vigor benih serta menurunkan infeksi patogen C. capsici (Kumalasari 2005). Hasil penelitian sebelumnya menunjukkan bahwa penggunaan mikroorganisme melalui aplikasi pada benih sebelum tanam secara nyata meningkatkan produksi cabai (Ilyas 2006). Selain memacu pertumbuhan tanaman, mikroorganisme juga dapat mengendalikan patogen tanaman. Sebanyak 25 isolat yang diuji, isolat BG25 dari kelompok Bacillus spp., P. fluorescens PG01 dari kelompok Pseudomonas spp., dan SG01 dari kelompok Serratia spp. memberikan efek yang lebih baik dalam menghambat pertumbuhan koloni $C$. capsici dan meningkatkan pertumbuhan bibit cabai dibandingkan dengan isolat lainnya dalam kelompok yang sama (Sutariati et al. 2006).
Pada penelitian ini dilakukan seleksi terhadap 23 rizobakteri koleksi Balitro (Balai Penelitian Tanaman Obat dan Aromatik) dengan tujuan memperoleh isolat rizobakteri yang efektif dalam menghambat pertumbuhan $P$. capsici. Rizobakteri yang efektif menghambat pertumbuhan $P$. capsici digunakan untuk melapisi benih cabai dengan tujuan untuk mengendalikan $P$. capsici, meningkatkan vigor benih, dan pertumbuhan tanaman.

\section{BAHAN DAN METODE}

Penelitian ini dilaksanakan di Laboratorium Penyakit Balitro, Laboratorium Kesehatan Benih, dan Rumah Kaca Cikabayan, Departemen Agronomi dan Hortikultura, Fakultas Pertanian, Institut Pertanian Bogor dari bulan Juli sampai Oktober 2013. Bahan yang digunakan pada penelitian ini adalah benih cabai merah (Capsicum annuum L.) varietas Laris, isolat Phytophthora capsici, 23 isolat rizobakteri koleksi Balitro, PDA (potato dextrose agar), alkohol $70 \%$, metalaksil, pupuk kandang, NPK $50 \mathrm{ml}$ per tanaman, dan kompos. Alat yang digunakan adalah cawan petri, spektrofotometer, polybag, tray, timbangan analitik, jarum ose, jarum inet, erlenmeyer, penggaris, autoklaf, dan laminar air flow cabinet.

\section{Seleksi keefektifan isolat rizobakteri}

Seleksi keefektifan isolat rizobakteri dilakukan dengan metode dual culture. Isolat $P$. capsici yang telah ditumbuhkan pada media PDA (potato dextrose agar) dipotong dengan diameter $0.5 \mathrm{~cm}$ kemudian dipindahkan ke media PDA baru dengan jarak $3 \mathrm{~cm}$ dari tepi cawan petri. Isolat rizobakteri yang diuji digoreskan memanjang dengan jarak $3 \mathrm{~cm}$ dari tepi cawan petri berlawanan arah dengan letak patogen. Pengujian dual culture ini dilakukan dengan tiga ulangan. Pengamatan dilakukan setiap hari terhadap pertumbuhan koloni patogen, dan persentase daya hambat $(\mathrm{DH})$ rizobakteri dihitung dengan rumus:

$$
\mathrm{DH}=\frac{R 1-R 2}{R 1} x 100 \%
$$

Keterangan:

$\mathrm{R} 1=$ jari-jari pertumbuhan patogen tanpa rizobakteri (kontrol) 
$\mathrm{R} 2=$ jari-jari pertumbuhan patogen ke arah rizobakteri (Syamsudin 2010)

\section{Perlakuan benih dengan rizobakteri}

Benih cabai sebelum diberi perlakuan terlebih dahulu didisinfeksi dengan merendam benih dalam alkohol $70 \%$ selama tiga menit. Selanjutnya benih dicuci sebanyak tiga kali dengan aquades yang telah disterilkan dalam autoklaf pada suhu $121^{\circ} \mathrm{C}$, tekanan 1.02 atm selama 15 menit. Benih yang telah dicuci dikering-anginkan dalam laminar air flow cabinet selama 60 menit. Benih yang telah dikeringanginkan diberi perlakuan dengan cara direndam dalam suspensi isolat rizobakteri masing-masing $(50 \mathrm{ml})$ atau dalam suspensi metalaksil $10 \mathrm{mg}$ dalam $50 \mathrm{ml}$ air selama 24 jam pada suhu $26^{\circ} \mathrm{C}$. Suspensi sel rizobakteri dibuat dengan menginkubasi setiap rizobakteri dalam $50 \mathrm{ml}$ potato dextrose (PD) selama 48 jam, kemudian dilihat nilai optical density (OD) tersebut menggunakan spektrofotometer agar diketahui kerapatan rizobakteri tersebut. Kerapatan dari ketiga rizobakteri tersebut adalah $10^{8} \mathrm{cfu}$. Benih yang telah diberi perlakuan kemudian dikeringanginkan dalam laminar air flow cabinet selama 60 menit sebelum ditanam (Syamsudin 2010). Benih yang tidak diberi perlakuan dijadikan sebagai kontrol pada persemaian, setelah menjadi bibit kemudian diambil 40 untuk bibit tanpa perlakuan dan tanah tidak diinokulasi $P$. capsici (kontrol negatif) dan 40 untuk bibit tanpa perlakuan rizobakteri tetapi tanah diinokulasi $P$. capsici (kontrol positif).

\section{Pengaruh perlakuan benih dengan rizobakteri}

Benih yang sudah diberi perlakuan pelapisan rizobakteri kemudian disemai pada tray semai yang berisi campuran tanah dan kompos steril $(1: 1 \mathrm{v} / \mathrm{v})$. Setelah bibit cabai berumur 35 hari, bibit dipindahkan ke polybag (satu bibit per polybag) berukuran $30 \mathrm{~cm}$ x $35 \mathrm{~cm}$. Media tanam yang digunakan adalah campuran tanah dan pupuk kandang $(4: 1 \mathrm{v} / \mathrm{v})$. Setelah bibit dipindah tanam, media tanah kemudian diinokulasi dengan $P$. capsici (kecuali untuk perlakuan kontrol negatif) dengan cara tanah yang berinokulum $P$. capsici diletakkan di lapisan atas media tanah tersebut sebanyak $10 \mathrm{~g}$ pada setiap polybag. Tanah inokulum dibuat berdasarkan metode Manohara (1988) sebagai berikut: tanah dikeringkan sebanyak $2 \mathrm{~kg}$, kemudian dicampur dengan $4 \%$ oat meal dan diberi air secukupnya hingga membasahi seluruh campuran tanah dan oat meal. Kemudian disterilkan dengan autoklaf pada suhu $120{ }^{\circ} \mathrm{C}$ selama 20 menit. Kemudian potongan biakan $P$. capsici diinvestasikan ke tanah yang sudah steril. Setelah itu diinkubasi pada suhu ruangan $\left(23-25{ }^{\circ} \mathrm{C}\right)$ selama dua minggu. Penyiraman dilakukan setiap hari agar pertumbuhan dan perkembangan bibit normal. Pemupukan tanaman menggunakan pupuk NPK $50 \mathrm{ml}$ per tanaman.

Penelitian ini dilakukan terdiri atas dua tahap percobaan, keduanya menggunakan rancangan acak lengkap (RAL) satu faktor. Percobaan pertama terdiri atas lima taraf yaitu: tanpa perlakuan rizobakteri (kontrol), perlakuan rizobakteri ST116B, perlakuan rizobakteri ST156, perlakuan rizobakteri E3, dan perlakuan metalaksil. Setiap perlakuan diulang empat kali sehingga tedapat 20 satuan percobaan. Setiap satuan percobaan menggunakan 50 benih sehingga terdapat 1200 satuan pengamatan. Percobaan kedua terdiri atas enam taraf yaitu tanpa perlakuan rizobakteri dan tanpa inokulasi $P$. capsici atau kontrol negatif (K-); tanpa perlakuan dan diinokulasi $P$. capsici atau kontrol positif $(\mathrm{K}+)$; perlakuan rizobakteri ST116B; perlakuan rizobakteri ST156; perlakuan rizobakteri E3; dan perlakuan menggunakan fungisida sintetis metalaksil (M). Setiap perlakuan diulang empat kali sehingga terdapat 24 perlakuan. Setiap satuan percobaan menggunakan 10 bibit sehingga terdapat 240 bibit cabai.

Model aditif rancangan percobaan:

Keterangan :

$$
\mathbf{Y}_{\mathrm{ij}}=\boldsymbol{\mu}+\boldsymbol{\alpha}_{\mathrm{i}}+\varepsilon_{\mathrm{ij}}
$$

$\mu=$ Nilai tengah perlakuan

$\alpha_{\mathrm{i}}=$ Pengaruh rizobakteri ke- $\mathrm{i}$

$\varepsilon_{\mathrm{ij}}=$ Pengaruh galat percobaan

Analisis data dilakukan dengan metode analisis ragam. Jika terdapat perbedaan nyata antar perlakuan maka dilakukan uji lanjut dengan metode beda nyata terkecil (BNT) pada $\alpha=5 \%$. Pengamatan: (1) Daya hambat rizobakteri terhadap pertumbuhan $P$. capsici, (2) Zona bening (ruang di antara rizobakteri dan $P$. capsici), (3) Daya berkecambah (DB) (4) Indeks vigor (IV), (5) Keserempakan tumbuh $\left(\mathrm{K}_{\mathrm{S}} \mathrm{t}\right)$, (6) Kecepatan tumbuh $\left(\mathrm{K}_{\mathrm{CT}}\right)$, (7) Kejadian penyakit, (8) Tinggi tanaman, dan (9) Jumlah daun.

\section{HASIL DAN PEMBAHASAN}

Hasil pengamatan jari-jari pertumbuhan $P$. capsici pada hari keempat setelah rizobakteri dan $P$. capsici ditumbuhkan dapat dilihat pada 
Tabel 1. Pertumbuhan P. capsici pada perlakuan tanpa rizobakteri (kontrol), mencapai diameter 90 $\mathrm{mm}$ atau memenuhi cawan petri.

Tabel 1. Kemampuan isolat rizobakteri dalam menghambat pertumbuhan P. capsici

\begin{tabular}{|c|c|c|c|c|c|}
\hline \multirow{2}{*}{$\begin{array}{l}\text { Isolat } \\
\text { rizobakteri }\end{array}$} & \multirow{2}{*}{$\begin{array}{c}\text { Daya hambat terhadap } \\
\text { P. capsici }(\%)^{\mathrm{a}}\end{array}$} & \multicolumn{4}{|c|}{ Rata - rata ruang kosong/ zona bening $(\mathrm{mm})$} \\
\hline & & $\begin{array}{c}\text { pengamatan } \\
\text { (hari ke-6) }\end{array}$ & $\begin{array}{l}\text { pengamatan } \\
\text { (hari ke-7) }\end{array}$ & $\begin{array}{c}\text { pengamatan } \\
\text { (hari ke-8) }\end{array}$ & $\begin{array}{l}\text { Pengamatan } \\
\text { (hari ke-9) }^{\mathrm{a}}\end{array}$ \\
\hline Kontrol & $0 \mathrm{~g}$ & 0 & 0 & 0 & $0 \mathrm{~g}$ \\
\hline ST156* & $58 \mathrm{a}$ & $24 *$ & $24 *$ & $24 *$ & $24^{*} \mathrm{a}$ \\
\hline ST125 & $57 \mathrm{ab}$ & 24 & 22 & 22 & 14 bcdef \\
\hline ST109B & $51 \mathrm{abc}$ & 20 & 18 & 18 & 18 abcde \\
\hline ST116B* & $50 \mathrm{abc}$ & $20 *$ & $20 *$ & $20 *$ & $20^{*} \mathrm{abc}$ \\
\hline SK7 & $49 \mathrm{abc}$ & 21 & 19 & 19 & 19 abcd \\
\hline OGIC & $47 \mathrm{abc}$ & 20 & 14 & 12 & 12 bcdef \\
\hline SK14 & $47 \mathrm{abc}$ & 20 & 16 & 12 & 12 bcdef \\
\hline E3* & $47 \mathrm{abc}$ & $21 *$ & $21^{*}$ & $21^{*}$ & $21^{*} \mathrm{ab}$ \\
\hline ST77 & $47 \mathrm{abc}$ & 20 & 18 & 18 & 16 abcdef \\
\hline ST116 & $46 a b c$ & 19 & 19 & 18 & 18 abcde \\
\hline SK1 & $46 \mathrm{abc}$ & 20 & 18 & 15 & 15 abcdef \\
\hline SK18 & $45 \mathrm{abc}$ & 20 & 18 & 18 & 13 bcdef \\
\hline ST81 & $44 a b c$ & 20 & 19 & 19 & 19 abcd \\
\hline ST124 & $43 \mathrm{bcd}$ & 18 & 16 & 16 & 16 abcdef \\
\hline SK5 & 40 cde & 17 & 17 & 16 & 16 abcdef \\
\hline CM58 & 37 cde & 16 & 7 & 7 & $7 \mathrm{fg}$ \\
\hline ST109 & 30 def & 12 & 10 & 10 & $10 \mathrm{def}$ \\
\hline ST107 & 29 ef & 13 & 12 & 12 & 12 bcdef \\
\hline CM49 & $28 \mathrm{ef}$ & 12 & 9 & 9 & 8 efg \\
\hline CM55 & $27 \mathrm{ef}$ & 10 & 0 & 0 & $0 \mathrm{~g}$ \\
\hline SK10 & $17 \mathrm{f}$ & 8 & 0 & 0 & $0 \mathrm{~g}$ \\
\hline SK19 & $50 \mathrm{abc}$ & 21 & 20 & 19 & $18 \mathrm{abcd}$ \\
\hline SK2 & $37 \mathrm{def}$ & 16 & 11 & 11 & $11 \mathrm{cdef}$ \\
\hline KK & 16.07 & & & & 41.46 \\
\hline F hitung & 0.001 & & & & 0.001 \\
\hline
\end{tabular}

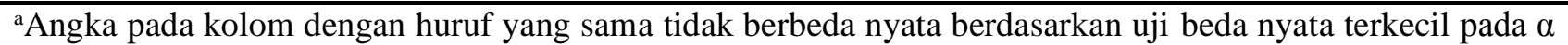
$=5 \%$; *rizobakteri yang digunakan

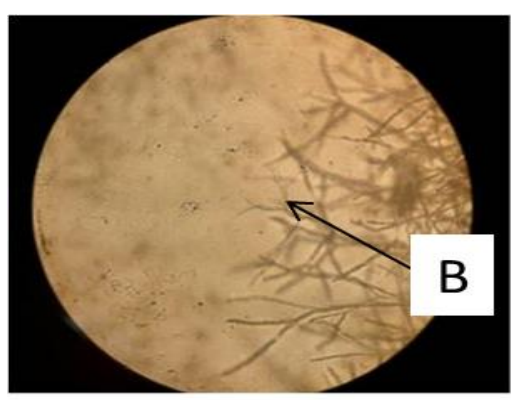

$\mathbf{E 3}$

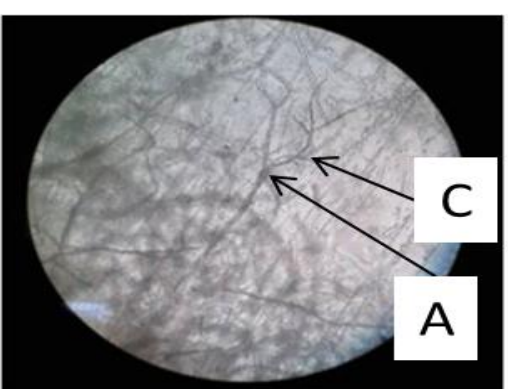

ST156

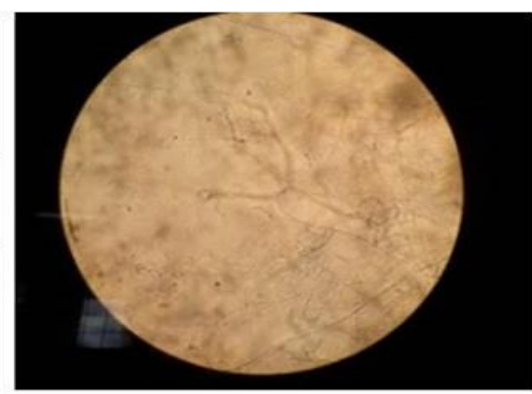

ST116B

Gambar 1. Pertumbuhan hifa P. capsici yang membesar (a), mengalami lisis (b), dan lilitan (c) (pembesaran 40x10) 


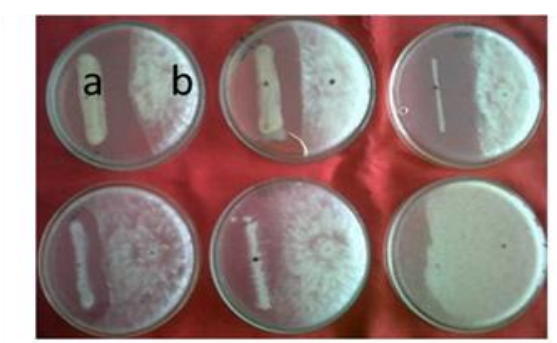

Perbedaan daya hambat beberapa rizobakteri

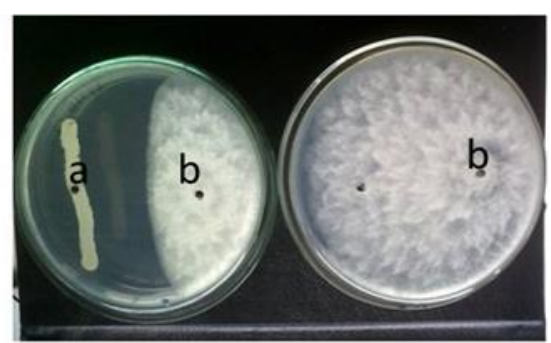

Rizobakteri dan kontrol

Gambar 2. Pertumbuhan hifa $P$. capsici yang yang tertekan akibat rizobakteri secara makroskopis, $\mathrm{a}=$ rizobakteri dan $\mathrm{b}=P$. capsici

Semua isolat rizobakteri yang diuji memiliki nilai yang sangat nyata lebih tinggi dibanding kontrol sehingga rizobakteri tersebut berpotensi menghambat pertumbuhan $P$. capsici. Persentase daya hambat dari 23 isolat rizobakteri berkisar $17-58 \%$. Isolat rizobakteri yang memiliki daya hambat paling rendah adalah isolat SK10 yaitu $17 \%$ sedangkan daya hambat paling tinggi adalah isolat ST156 yaitu 58\%. Terdapat 14 isolat rizobakteri pada uji antagonis yang memiliki nilai lebih tinggi dibanding beberapa isolat lain yaitu: ST81 sebesar 44\%, SK18 45\%, SK1 dan ST116 $46 \%$, ST77, E3, SK14 dan OG1C 47\%, SK7 49\%, ST116B dan SK19 50\%, ST109B 51\%, ST125 57\%, dan ST156 58\%.

Pengamatan ruang kosong atau zona bening di antara pertumbuhan hifa dari patogen $P$. capsici dan rizobakteri menunjukkan bahwa terdapat 19 isolat rizobakteri yang memiliki nilai yang sangat nyata lebih tinggi dibanding kontrol yaitu: ST156, E3, ST116B, SK19, ST81, SK7, ST116, ST109B, SK5, ST77, ST124, SK1, ST125, SK18, ST107, SK14, OGIC, SK2, dan ST109 sedangkan isolat CM49, CM58, CM55, dan SK10 tidak berbeda nyata dengan kontrol.
Menurut Sutariati (2006) tidak semua isolat rizobakteri mampu memproduksi enzim ekstraseluler seperti kitinase, protease, dan lipase dan mampu mensintesis senyawa asam sianida $(\mathrm{HCN})$. Senyawa HCN merupakan senyawa metabolit sekunder yang dihasilkan oleh rizobakteri yang bersifat toksik bagi patogen.

Sebanyak 7 dari 14 isolat rizobakteri dengan daya hambat lebih tinggi memiliki zona bening yang relatif konstan yaitu: ST156, E3, ST116B, ST81, SK7, ST116, dan ST109B. Rizobakteri tersebut dapat menghambat pertumbuhan koloni $P$. capsici secara in vitro. Secara mikroskopis terlihat rizobakteri yang diuji dapat mendegradasi dinding sel $P$. capsici (Gambar 1), hal ini dibuktikan dengan adanya jarak pada daerah hambatan atau ruang kosong di antara pertumbuhan rizobakteri dan $P$. capsici tersebut yang terlihat pada Gambar 2. Degradasi dinding sel diduga karena rizobakteri mampu mensekresi enzim ekstraseluler. Rizobakteri kelompok Bacillus spp. dapat mensekresikan enzim ekstraseluler (protease atau selulase) sehingga mampu menghambat pertumbuhan koloni P. capsici (Syamsudin 2010).

Tabel 2. Pengaruh perlakuan benih dengan rizobakteri terhadap viabilitas dan vigor benih cabai

\begin{tabular}{lcccc}
\hline $\begin{array}{c}\text { Perlakuan } \\
\text { Benih }\end{array}$ & $\begin{array}{c}\text { Daya berkecambah } \\
(\%)\end{array}$ & $\begin{array}{c}\text { Indeks vigor } \\
(\%)^{\mathrm{a}}\end{array}$ & $\begin{array}{c}\text { Keserempakan tumbuh } \\
(\%)\end{array}$ & $\begin{array}{c}\text { Kecepatan tumbuh } \\
(\%)\end{array}$ \\
\hline St156 & 92.00 & $11.50 \mathrm{a}$ & 86.00 & 54.20 \\
St116b & 86.00 & $17.50 \mathrm{a}$ & 77.50 & 52.30 \\
E3 & 91.00 & $12.00 \mathrm{a}$ & 79.50 & 52.20 \\
Metalaksil & 81.00 & $15.50 \mathrm{a}$ & 73.30 & 51.40 \\
Tanpa & 75.00 & $1.30 \mathrm{~b}$ & 71.50 & 43.10 \\
perlakuan & & & & \\
KK & 12.24 & 24.66 & 15.13 & 15.55 \\
F hitung & 0.19 & 0.002 & 0.47 & 0.34 \\
\hline
\end{tabular}

${ }^{a}$ Angka pada kolom dengan huruf yang sama tidak berbeda nyata berdasarkan uji beda nyata terkecil pada $\alpha$ $=5 \%$; data indeks vigor ditransformasi dengan rumus $\sqrt{x+0.5}$ 


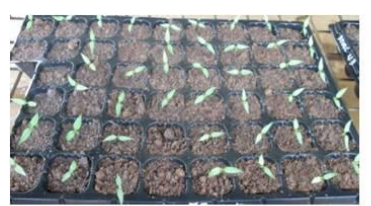

E3

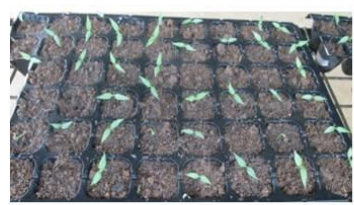

Metalaksil

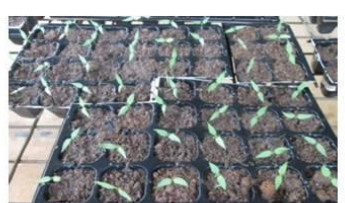

ST156

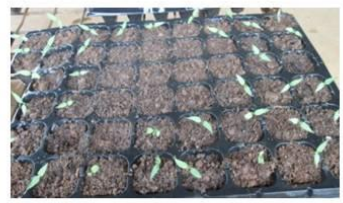

Kontrol

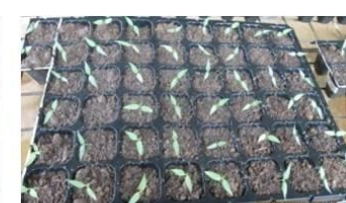

ST116B

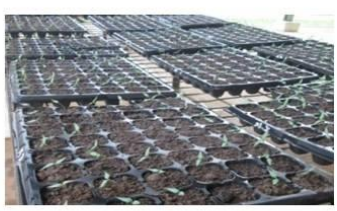

Persemaian

Gambar 3. Perkecambahan cabai dari benih yang telah dilapisi rizobakteri, metalaksil, dan tanpa perlakuan (kontrol)

Pada Tabel 2 hasil pengamatan terhadap tolok ukur daya berkecambah (jumlah persentase kecambah normal hari ke-7 dan hari ke-10) menunjukkan nilai yang tidak berbeda nyata antara semua perlakuan. Indeks vigor (persentase kecambah normal pada hari ke-7 setelah benih ditanam) menunjukkan bahwa benih yang diberi perlakuan dengan rizobakteri dan metalaksil memiliki nilai yang nyata lebih tinggi dibanding kontrol. Pengamatan untuk keserempakan tumbuh pada hari ke-10 setelah benih ditanam dan pengamatan untuk kecepatan tumbuh pada setiap hari selama 14 hari setelah benih ditanam menunjukkan semua perlakuan dan kontrol memiliki nilai tidak berbeda nyata.
Peningkatan vigor yang terlihat pada persentase indeks vigor benih yang diberi perlakuan rizobakteri dan metalaksil disebabkan karena benih tersebut terlebih dahulu mengalami imbibisi (proses penyerapan air). Menurut Ilyas et al. (2002) perlakuan invigorasi secara nyata meningkatkan viabilitas dan vigor benih cabai. Jumlah kecambah normal pada semua perlakuan rizobakteri cenderung lebih banyak dibanding perlakuan metalaksil dan kontrol (Gambar 3) diduga ketiga rizobakteri tersebut mampu memproduksi fitohormon diantaranya giberelin dan IAA (indole acetic acid) sebagai pemicu pertumbuhan.

Tabel 3. Pengaruh perlakuan benih dengan rizobakteri terhadap jumlah daun dan tinggi tanaman pada 5 MSP dan 7 MSP

\begin{tabular}{lcccc}
\hline \multirow{2}{*}{ Perlakuan rizobakteri } & \multicolumn{2}{c}{ Jumlah daun $^{\mathrm{a}}$} & \multicolumn{2}{c}{ Tinggi tanaman (cm) } \\
\cline { 2 - 5 } & $5 \mathrm{MSP}$ & $7 \mathrm{MSP}$ & $5 \mathrm{MSP}$ & 7 MSP \\
\hline ST116B & $13.9 \mathrm{ab}$ & $39.3 \mathrm{a}$ & 20.3 & 36.2 \\
ST156 & $14.3 \mathrm{a}$ & $32.4 \mathrm{~b}$ & 18.1 & 32.8 \\
E3 & $13.1 \mathrm{abc}$ & $30.2 \mathrm{~b}$ & 17.2 & 32.6 \\
Metalaksil & $12.3 \mathrm{c}$ & $29.3 \mathrm{~b}$ & 16.3 & 29.9 \\
Kontrol positif* & $12.4 \mathrm{bc}$ & $29.5 \mathrm{~b}$ & 17.9 & 31.4 \\
Kontrol negatif* & $12.4 \mathrm{c}$ & $28.8 \mathrm{~b}$ & 17.4 & 31.3 \\
KK & 7.83 & 13.06 & 12.70 & 13.02 \\
F hitung & 0.04 & 0.01 & 0.26 & 0.49 \\
\hline
\end{tabular}

${ }^{a}$ Angka pada kolom dengan huruf yang sama tidak berbeda nyata berdasarkan uji beda nyata terkecil pada $\alpha$ $=5 \% ; \mathrm{MSP}=$ minggu setelah pindah tanam; "kontrol positif (tanpa perlakuan rizobakteri dan tanah diinokulasi $P$. capsici), kontrol negatif (tanpa perlakuan rizobakteri dan tanah tidak diinokulasi $P$. capsici) 

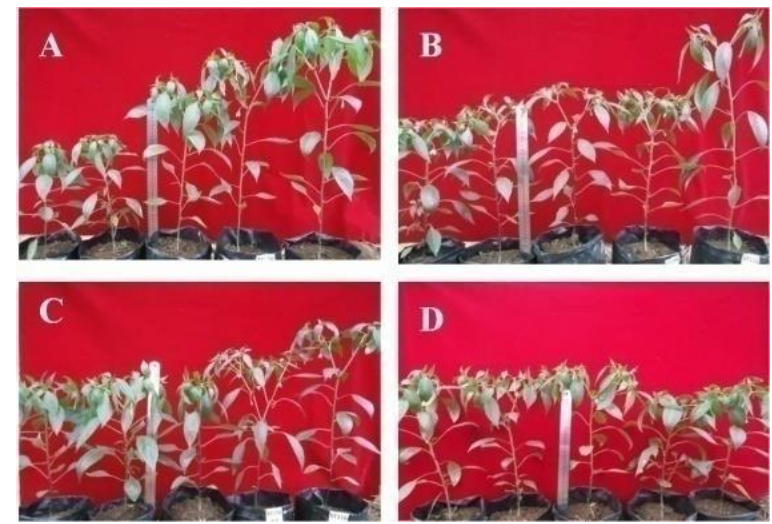

Gambar 4. Performa pertumbuhan tinggi tanaman cabai (ket: kiri ke kanan secara berurutan dimulai dari kontrol, metalaksil, E3, ST156, dan ST116B; A= ulangan 1, B= ulangan 2, C= ulangan 3, D= ulangan 4)

Pada 5 MSP, jumlah daun pada perlakuan rizobakteri ST156 menunjukkan nilai yang nyata lebih tinggi dibanding metalaksil, kontrol positif, dan kontrol negatif sedangkan rizobakteri tersebut tidak berbeda nyata dengan ST116B dan E3. Pada 7 MSP, jumlah daun yang memiliki nilai yang nyata lebih tinggi dari semua perlakuan hanya terlihat pada perlakuan rizobakteri ST116B. Tinggi tanaman tidak menunjukkan nilai yang berbeda nyata pada semua perlakuan baik pada 5 MSP maupun 7 MSP, perlakuan rizobakteri ST116B cenderung memiliki tinggi tanaman yang lebih tinggi dari semua perlakuan (Gambar 4). Peningkatan jumlah daun diduga rizobakteri ini mampu menyediakan dan memobilisasi penyerapan unsur hara untuk tanaman. Selain itu, rizobakteri ini juga diduga mampu menghasilkan senyawa pemicu pertumbuhan salah satunya adalah IAA (indole acetic acid). Menurut Sutariati et al. (2006) rizobakteri mampu memproduksi IAA dalam media dengan menambahkan asam amino triptofan. Menurut Syamsudin (2010) sebanyak 37 isolat rizobakteri yang diuji semuanya mampu memproduksi IAA.

Kemampuan rizobakteri sebagai pemicu pertumbuhan tanaman atau plant growth promoting rhizobacteria (PGPR) dapat memproduksi fitohormon seperti IAA, giberelin, sitokinin, dan etilen dalam lingkungan akar. Selain itu, rizobakteri PGPR juga dapat menyediakan hara (biofertilizers) dengan menambat $\mathrm{N}_{2}$ dari udara secara asimbiosis dan dapat melarutkan hara $\mathrm{P}$ yang terikat dalam tanah (Tenuta 2006). Kecenderungan peningkatan pertumbuhan bibit cabai pada isolat rizobakteri yang mampu melarutkan fosfat lebih baik dibanding pada isolat rizobakteri yang tidak mampu melarutkan fosfat (Syamsudin 2010). Selain itu, perlakuan benih menggunakan rizobakteri dapat meningkatkan pertumbuhan tanaman dan hasil cabai (Sutariati dan Safuan 2012).

Hasil pengamatan terhadap serangan penyakit busuk phytophthora pada 28 hari setelah aplikasi (Tabel 4) menunjukkan bahwa tanaman yang diberi perlakuan rizobakteri ST116B dan tanaman kontrol negatif tidak terlihat gejala serangan penyakit busuk phytophthora. Namun, pada tanaman yang diberi perlakuan rizobakteri ST156, E3, metalaksil, dan kontrol positif menunjukkan adanya serangan Phytophthora capsici dengan persentase serangan berkisar 5-7 $\%$. Gejala serangan yang terlihat adalah batang yang mengalami discoloration berwarna coklat kemudian seluruh bagian daun layu dan tanaman mengering. Selanjutnya muncul miselium dari $P$. capsici berwarna putih pada permukaan batang yang diserang dan tanaman mati (Gambar 5).

Tabel 4. Pengaruh perlakuan rizobakteri terhadap kejadian penyakit 28 hari setelah aplikasi

\begin{tabular}{lc}
\hline Perlakuan rizobakteri & Kejadian penyakit $(\%)$ \\
\hline ST116B & 0 \\
ST156 & 7.5 \\
E3 & 5 \\
Metalaksil & 5 \\
Kontrol positif* $^{*}$ & 5 \\
Kontrol negatif & 0 \\
KK & 39.39 \\
F hitung & 0.54 \\
\hline
\end{tabular}

"kontrol positif (benih tanpa perlakuan rizobakteri tetapi tanah diinokulasi $P$. capsici), kontrol negatif (benih tanpa perlakuan rizobakteri dan tanah tidak diinokulasi $P$. capsici); seluruh data ditransformasi dengan rumus $\sqrt{x+3.5}$ 

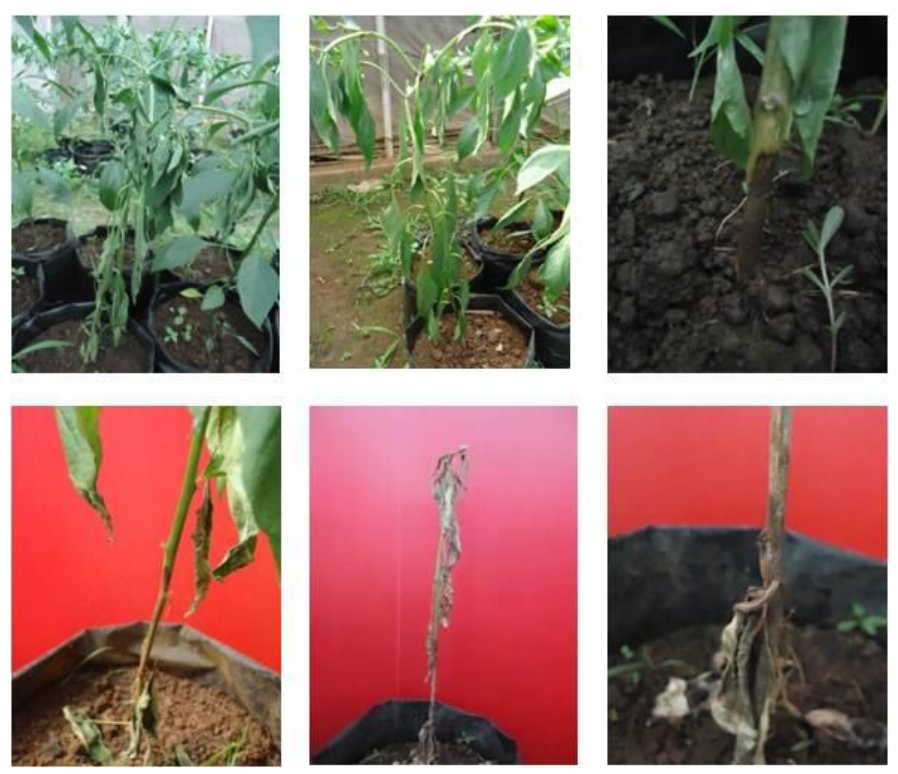

Gambar 5. Tanaman cabai yang terserang Phytophthora capsici

Menurut Syamsudin (2010) gejala penyakit busuk phytophthora pada pangkal batang 12 hari setelah inokulasi dimulai dengan munculnya nekrosis pada pangkal batang. Nekrosis tersebut berkembang disertai pembusukan pada permukaan batang. Perluasan nekrosis pada batang diikuti oleh terjadinya perubahan warna batang dari tepi lesio dari warna coklat muda menjadi coklat kehitaman dan bagian lesio mengeras. Pada hari ke-14, miselium berwarna putih mulai terbentuk pada bagian permukaan batang yang membusuk dan sebagian daun layu kemudian tanaman mati.

Persentase kejadian penyakit pada perlakuan ST116B tidak mengalami gejala serangan penyakit busuk phytophthora. Menurut Syamsudin (2010) adanya perbedaan daya hambat antar rizobakteri berhubungan dengan kemampuan dalam mensekresikan senyawa metabolit sekunder yang bersifat anti mikrob. Persentase kejadian penyakit relatif kecil, hal ini diduga jumlah tanah inokulum yang diaplikasikan sedikit. Syamsudin (2010) menyatakan bahwa metode inokulasi yang baik adalah tanah inokulum ditebar di sekitar bibit dan pangkal batang dilukai dengan lima tusukan jarum.

\section{KESIMPULAN}

Rizobakteri ST156, E3, ST116B, ST81, SK7, ST116, dan ST109B, secara in vitro menghambat pertumbuhan patogen Phytophthora capsici. Rizobakteri tersebut dapat digunakan sebagai agens hayati untuk mengendalikan penyakit busuk phytophthora. Perlakuan benih menggunakan rizobakteri ST116B, ST156, dan E3 nyata meningkatkan vigor benih pada tolok ukur indeks vigor. Rizobakteri ST116B mampu meningkatkan pertumbuhan tanaman pada tolok ukur jumlah daun dan berpotensi mengendalikan penyakit busuk phytophthora pada tanaman cabai.

\section{DAFTAR PUSTAKA}

Agustiansyah. 2011. Perlakuan Benih untuk Perbaikan Pertumbuhan Tanaman, Hasil dan Mutu Benih Padi serta Pengendalian Penyakit Hawar Daun Bakteri dan Pengurangan Penggunaan Pupuk Fosfat [Disertasi]. Bogor (ID): Institut Pertanian Bogor.

Azizah, M. 2011. Pengaruh Aplikasi Isolat Methylobacterium spp terhadap Pertumbuhan dan Daya Hasil Tanaman Cabai (Capsicum annuum L.)[Skripsi]. Bogor (ID): Institut Pertanian Bogor.

Copeland, L.O., Mc Donald M.B. 1995. Principles of Seed Science and Tecnology. New York (US): Chapman and Hall.

Ilyas, S. 2006. Review: Seed treatments using matriconditioning to improve vegetable seed quality. Buletin Agronomi vol. 34(2):124-132.

Ilyas, S, Sutariati G.A.K, Suwarno F.C., Sudarsono. 2002. Matriconditioning improves the quality and protein level of 
medium vigor hot pepper seed. J. Seed Technol 24:66-75.

Kumalasari, V. 2005. Pengaruh Agens Biokontrol Terhadap Pertumbuhan Colletotrichum capsici Secara invitro dan Mutu Benih Cabai (Capsicum annuum L.)[Skripsi]. Bogor (ID): Institut Pertanian Bogor.

Kusandriani, Y. 1995. Botani Tanaman Cabai Merah. Duriat A.S., Hadisoegandi, Soetiarso T.A. dan Praniangum, editor. Bandung (ID). Balai Penelitian Tanaman Sayuran.

Manohara. 1988. Ekologi Phytophthora palmivora (Bulter), Penyebab Penyakit Busuk Pangkal Batang Lada (Piper nigrum L.) [Disertasi]. Bogor (ID): Institut Pertanian Bogor.

Sinaga, M.S. 2003. Dasar-dasar Ilmu Penyakit Tumbuhan Seri Agriteks. Penebar. Jakarta.

Sutariati, G.A.K., Sofuan L.O. 2012. Perlakuan benih dengan rizobakteri meningkatkan benih dan hasil cabai. J. Agron. 40(2): 125-131.

Sutariati, G.A.K., Widodo, Sudarsono, Ilyas S. 2006. Karakter fisiologis dan keefektifan isolat rizobakteri sebagai agens antagonis Colletotrichum capsici dan rizobakteri pemacu pertumbuhan tanaman cabai. Jurnal Ilmiah Pertanian KULTURA. Vol. 41(1): 28-34.

Sutariati, G.A.K., Widodo, Sudarsono, Ilyas S. 2006. Perlakuan rizobakteri pemicu pertumbuhan tanaman terhadap viabilitas benih serta pertumbuhan tanaman cabai. B Agronom. 34 (1): 46-54.

Syamsudin. 2010. Perlakuan Benih untuk Pengendalian Penyakit Busuk Phytophthora, Peningkatan Hasil dan Mutu Benih Cabai Merah (Capsicum annuит L) [Disertasi]. Bogor (ID). Institut Pertanian Bogor.

Tenuta. 2006. Plant Growth Promoting Rhizobacteria: prospect for increasing nutrient acquisition and disease control. Tersedia pada http://tenuta rhiz obacteria.pdf. [15 Oktober 2013]. 